\title{
The Digital Teacher: Promises and Challenges
}

Aly Abdul Samea Qoura

Faculty of Education, Mansoura University, Egypt

DOI:

\section{Introduction}

This article deals with the digital teaching as a new trend in the EFL/ESL profession. Digital teaching is defined; its characteristics are delineated; processes are explained and promises and challenges are reported. Salient writings and viewpoints of respected academic authorities in the field of ELT and educational Technology were put together to highlight the spread of digital teaching and its repercussions on students, teachers, parents, curriculum designers and administrators.

With the advent of Internet and multiple formats that can be communicated over the World Wide Web, we now have several new and exciting ways to present information. The web allows the incorporation of animation' moving pictures, and sound into lessons which extends our abilities to present materials that encourage students' interaction with the subject matter. Pictures and animations help bring to life scientific principles and multimedia allows students to take a more active role in learning. In language teaching and learning, we have a lot to choose from the world of technology: Radio, TV, CD Rom, Computers, C.A.L.L., the
Internet, Electronic Dictionary, Email, Blogs and Audio Cassettes, Power Point, Videos, DVD's or VCD's.

Students read their texts as e-books on computers, tablets, and even cell phones, and communicate about assignments at a distance electronically. Digital tools help teachers manage their classrooms, communicate with students and parents, enhance learning with videos, simulations, and other multimedia accouterments, and assess student learning. However, despite the vast array of digital resources available, instructional designers are not realizing the full potential of these tools in curriculum, assessment, and teacher professional development materials. In recent years, the availability of online professional development has surged, providing teachers with easy access to high quality professional learning experiences. Much of these online materials are organized as interactive courses with a learning or content management environment presented in a more didactic approach of information transfer and tutorials (Fishman, 2016).

\section{Digital teaching}

Digital teaching refers to the ability to achieve $21^{\text {st }}$ century goals through digital age literacy, 
inventive thinking, effective communication, and high productivity. Digital Classrooms or Smart Classes, Digi classes, Computer Based Teaching, E-learning, Digital interactive classrooms, Smart schools, E-content rooms, Projector rooms etc., are terms used interchangeably to represent usage of digital technology in classrooms or in education.

\section{Digital natives}

The generation of young people, who were born around 1990s, may be called" digital natives", since they were born together with Internet and mobile technologies. Typical knowledge practices for this generation are claimed to be multi-tasking, that is, carrying out several activities side-by-side. They are also reading comfortably from screens, are fond of computer games, and are using social media extensively. Young people outsource many cognitive functions to different technological tools.

\section{Digital Classroom}

It is simply the ratio of devices to students. The digital classroom encompasses much more than a ratio. It is the opportunity for each student to use a Chromebook to enhance learning every day. And, it allows teachers to accelerate technology integration. Action is needed to promote innovation in the classroom and to take advantage of increased use of social media, open educational resources, and the rise data-driven learning and assessment. Consequently, this requires a new set of competences for teachers, teacher educators, and education leaders. Digital competence involves the confident and critical use of Information Society Technology (IST) and thus basic skills in Information and Communication Technology (ICT).

Terms associated with digital technologies in the classroom:

Cambridge Assessment International Education (2017) gives the following examples:

\begin{tabular}{|c|c|c|c|c|}
\hline Term & Definition & Example & Benefit(s) & $\operatorname{Risk}(\mathbf{s})$ \\
\hline $\begin{array}{l}\text { Bring your } \\
\text { own device } \\
\text { (BYOD) }\end{array}$ & $\begin{array}{l}\text { Learners bring their own } \\
\text { technology into the } \\
\text { classroom for use as part } \\
\text { of the learning activity. }\end{array}$ & $\begin{array}{l}\text { Mobile phone is } \\
\text { used to browse } \\
\text { the internet as } \\
\text { part of a } \\
\text { research } \\
\text { activity. }\end{array}$ & $\begin{array}{l}\text { Greater range } \\
\text { of technologies } \\
\text { available and } \\
\text { lower cost to } \\
\text { institution. }\end{array}$ & $\begin{array}{l}\text { 1. Difficult to control } \\
\text { and monitor usage } \\
\text { 2. some learners may } \\
\text { have better devices } \\
\text { than others } \\
\text { 3. lack of teacher } \\
\text { understanding/ } \\
\text { training }\end{array}$ \\
\hline
\end{tabular}




\begin{tabular}{|c|c|c|c|c|}
\hline Term & Definition & Example & Benefit(s) & $\operatorname{Risk}(\mathrm{s})$ \\
\hline E-portfolios & $\begin{array}{l}\text { Learners and } \\
\text { teachers create an } \\
\text { electronic } \\
\text { catalogue of work } \\
\text { that tracks their } \\
\text { learning journey. } \\
\text { This is usually } \\
\text { online and often } \\
\text { uses multimedia } \\
\text { files. }\end{array}$ & $\begin{array}{l}\text { A student portfolio of } \\
\text { artwork is presented } \\
\text { online through an e- } \\
\text { portfolio. This } \\
\text { includes scans of their } \\
\text { sketches, photographs } \\
\text { of displays and visits } \\
\text { to galleries, written } \\
\text { reflections, narrated } \\
\text { videos of the artist } \\
\text { (learner) at work and } \\
\text { an audio logbook. }\end{array}$ & $\begin{array}{l}\text { Provides a way } \\
\text { of quickly and } \\
\text { seamlessly } \\
\text { presenting a } \\
\text { wide variety of } \\
\text { material in } \\
\text { different } \\
\text { formats } \\
\text { including } \\
\text { details of } \\
\text { process. }\end{array}$ & $\begin{array}{l}\text { 1. Data security and } \\
\text { confidentiality } \\
\text { 2. Lack of teacher } \\
\text { understanding/ } \\
\text { training }\end{array}$ \\
\hline $\begin{array}{l}\text { Flipped } \\
\text { classroom }\end{array}$ & $\begin{array}{l}\text { Learners discover } \\
\text { new content before } \\
\text { the lesson from } \\
\text { online videos or } \\
\text { resources and then } \\
\text { apply this } \\
\text { knowledge in more } \\
\text { personalized work } \\
\text { in the classroom }\end{array}$ & $\begin{array}{l}\text { Learners watch a } \\
\text { video at home about } \\
\text { how sedimentary } \\
\text { rocks are transformed } \\
\text { into metamorphic } \\
\text { rocks. In class they } \\
\text { work in groups to } \\
\text { collaboratively create } \\
\text { a diagram explaining } \\
\text { this process of } \\
\text { transformation. }\end{array}$ & $\begin{array}{l}\text { Provides more } \\
\text { time for } \\
\text { activities that } \\
\text { promote deeper } \\
\text { understanding } \\
\text { and reflection }\end{array}$ & $\begin{array}{l}\text { 1. learners do not } \\
\text { understand or are } \\
\text { not able to access } \\
\text { the flipped } \\
\text { material } \\
\text { 2. flipped learning is } \\
\text { not appropriate } \\
\text { 3. misunderstandings } \\
\text { arise that are not } \\
\text { addressed in class } \\
\text { 4. lack of teacher } \\
\text { understanding/ } \\
\text { training } \\
\text { 5. ensuring resources } \\
\text { are up-to-date }\end{array}$ \\
\hline $\begin{array}{c}\text { Personal } \\
\text { Learning } \\
\text { Network } \\
\text { (PLN) }\end{array}$ & $\begin{array}{l}\text { a PLN is an } \\
\text { individual's loose } \\
\text { collection of links } \\
\text { with other people } \\
\text { or resources. The } \\
\text { aim of such a } \\
\text { network is to } \\
\text { facilitate an } \\
\text { exchange of ideas } \\
\text { that supports } \\
\text { learning }\end{array}$ & $\begin{array}{l}\text { Groups for example } \\
\text { on Twitter and/or } \\
\text { online and face-to-face } \\
\text { courses. } \\
\text { Links can be through, } \\
\text { for example: } \\
\text { online interest }\end{array}$ & $\begin{array}{l}\text { Access to a } \\
\text { wide range of } \\
\text { perspectives } \\
\text { and expertise } \\
\text { beyond the } \\
\text { confines of the } \\
\text { physical } \\
\text { institution }\end{array}$ & $\begin{array}{l}\text { 1. data security and } \\
\text { confidentiality } \\
\text { 2. accuracy of } \\
\text { information } \\
\text { 3. access to the } \\
\text { network } \\
\text { 4. lack of teacher } \\
\text { understanding/ } \\
\text { training }\end{array}$ \\
\hline
\end{tabular}




\begin{tabular}{|c|c|c|c|c|}
\hline Term & Definition & Example & Benefit(s) & Risk(s) \\
\hline $\begin{array}{l}\text { Virtual } \\
\text { Learning } \\
\text { Environme } \\
\text { nt (VLE) }\end{array}$ & $\begin{array}{l}\text { a VLE is an e-learning education } \\
\text { system that is web-based, but } \\
\text { modeled on conventional face- } \\
\text { to-face education. It provides } \\
\text { access to courses, course } \\
\text { content, assessments, homework, } \\
\text { links to external resources etc. }\end{array}$ & $\begin{array}{l}\text { Moodle } \\
\text { Blackboard }\end{array}$ & $\begin{array}{l}\text { easy way to } \\
\text { collate and } \\
\text { organize } \\
\text { courses and } \\
\text { information } \\
\text { flexibility of } \\
\text { access }\end{array}$ & $\begin{array}{l}\text { 1. software can } \\
\text { limit course } \\
\text { structure } \\
\text { 2. high level of } \\
\text { maintenance }\end{array}$ \\
\hline
\end{tabular}

\section{Digital Teacher}

A digital teacher is a tool that recently appeared in the fields of Science and Administration and is widely spreading in other fields of teaching and learning. Main characteristics of the digital teacher (tool) are summarized in the following points:

$>$ It is an authentic digital tool for teaching subject at school level using educational technology. It would drastically bring down the time and efforts spent by teacher in preparing the content and presenting it to the learners in the classroom.

$>$ It is a text independent e-learning material for learners, teachers and administrators that brings the whole world to your classroom with a single (finger) touch.

\section{How is it beneficial?}

The product allows the teacher to instruct students in the subject in such a manner that learning takes place through seeing and hearing, lecture and demonstration method.
* In this way, optimal delivery of learning experience can be ensured by the instructor.

- Pause/Play buttons embedded in the product allow the teacher to use the product at his or her own pace.

* Owing to its user-friendly features, school administrators can adopt this product as the standard teaching tool of the science subject in their institution.

\section{How does it work?}

The procedure of using the digital teacher goes as follows:

* The product presents a Unit Plan to the teachers which can either be adopted as it is or customized as per their needs in the planning stage of the instruction delivery.

* A template of the Lesson Plan is provided to break the instructions of a unit at class-toclass level on the lines of the unit plan.

* The pace of instruction delivery is placed in the hands of the teacher through the Overview section of the product which gives a bird's eye view of the subject matter of a unit. 
* A typical unit is divided into Introduction, Instruction and Evaluation sections on the lines of standard teaching-learning process.

* The content under Introduction section is divided into three sections, which helps the teacher to recall the previous knowledge, developing motivation and proper introduction of the subject.

* The content under Instruction section is divided into several types, namely, the "Concept Model / Activity", "Law / Principle", "Theory / Lab Activity", "Derivation / Numerical Problems" and "Uses/Applications", based on the nature of the science subjects.

* Concepts and processes presented using animation and procedures are shown using Simulations requiring intervention through a simple navigation system.

* At the completion of the syllabus, important instructions are presented in a nutshell for the recapitulation of the learners in the Summary section.

* Important Keywords are listed with links to the slides where the corresponding concept is covered in detail.

* The Reference section provides links to rich multimedia resources available on the internet for the teacher to explore further on the subject.
It is essential that the students remain mentally in touch with the subject matter taught in the classroom even after they leave the learning environment. For this reason, suggestions to the teachers on homework and project assignment for their students are provided under Follow-up Work section.

* The third aspect of teaching-learning process is Evaluation. On the same lines, the third section of the product is Evaluation. Here, a sample unit test paper covering the entire instructed unit is presented for the ease of the teacher and for mock assessment of the learner.

* A Dash Board to manage learning activities/ history of the user.

Book marking of the topics.

* Drawing Skills Section imparts the required drawing skills to the student

\section{The main characteristics of digital teaching}

Digital teaching has a number of unique aspects: Using authentic resources and activities; Online books; Hypermedia; Netiquette; Online tools and Multimedia, digital teaching aims at achieving Collaboration, communication and Skills of integration.

This teaching is after Learner-Centered Classroom and Personalized Instruction where students have access to any information possible, there certainly is no need to "spoon- 
feed" the knowledge or teach "one-size fits all" content. When students are allowed to make their own choices, they own their learning, increase intrinsic motivation, and put in more effort - an ideal recipe for better learning outcomes!

Students as Digital natives own expensive devices with capabilities to produce blogs, infographics, books, how-to videos, and tutorials, just to name a few, in many classes. When given a chance, students can produce beautiful and creative blogs, movies, or digital stories that they feel proud of and share with others.

Today's tools make it possible for EFL learners to go global to learn about other countries and people first hand. Of course, textbooks are still sufficient, yet, there is nothing like learning languages, cultures, and communication skills from actually talking to people from other parts of the world. Another important attribute is to go paperless -- organizing teaching resources and activities on one's own website and integrating technology bring students learning experience to a different level. Sharing links and offering digital discussions as opposed to a constant paper flow allows students to access and share class resources in a more organized fashion.

Connecting and collaborating are core aspects of digital teaching. Again, today's tools allow us to connect anyone, anywhere, anytime. Have a question for an expert or colleague? Simply connect via social media: follow, join, ask, or tell! Use blogs, Tweeters, etc. Connection, in turn, allows collaboration between teachers \& students. Creating digital resources, presentations, and projects together with other educators and students will make classroom activities resemble the real world.

You should expand your teaching toolbox and try new ways you have not tried before, such as teaching with social media or replacing textbooks with web resources. Not for the sake of tools but for the sake of students!

Digital learning is appearing as the panacea for all sorts of problems that ail the education sector. By embracing digital devices and connected learning, schools can not only connect to one another to boost learning or share insights, experience, and communications skills, but it also lets teachers enjoy a level playing field, where all types of schools have access to the same learning and opportunities.

Digital assessments provide students fast feedback on their understanding, letting both students and instructors concentrate their efforts on where further understanding is most required. Adaptive hinting provides guidance to corrects misperceptions, incorrect responses quickly and helps students to figure out issues real-time.

Digital teaching is driving teachers and learners beyond Google. Simply Googling an 
answer does not provide students with true, deep learning. And while most students understand how to use a search engine, it is up to teachers to provide students with the additional skills to bring the answers to the next level.

\section{Ways teachers can embed digital literacy skills into Internet searches:}

\section{Teach students to evaluate and question} their sources. Students need to know the difference between a trustworthy and untrustworthy source.

- Is their source an academic website or a marketing company?

- When the source was last updated?

- How many other sites link to this source as a reference?

- Is the information presented in objective or biased language?

Teach students how to draw a strong conclusion. It is not enough that students find the right answer to a problem, but what use is that search if they've only memorized the logic to get them there? It's up to teachers to teach that logic and to contextualize the answer.

Push students to new levels of creativity. Once students have a deeper understanding of the answers they've found, push for creative application of that knowledge. This could be anything from challenging students to pose related questions to having students use other digital platforms to create something new.

Again, digital literacy does not mean knowing how to use every piece of software students will encounter. Teachers should encourage students to seek out and learn the software they need to know in order to do what's required.

Digital age language teachers have a number of responsibilities:

1. To know the availability of the online resources and to make language learning effective.

\section{Context based selections of the resources} according to students group and develops suitable activities that will create opportunities for enhancing both language and digital skills. In doing so, teachers can encourage students to adopt alternative perspectives that create dialogic interactions and challenge status-quo perspectives.

3. Need to teach the skills necessary to function in the digital age, including reading and writing digital text and communicating and publishing online.

4. Digital literacy skills are done seamlessly and in an integrated manner so that the language course is a coherent whole rather than a collection of loose components.

5. Redefine criteria used to assess student learning in terms of digital literacies, using e-portfolios and digital assessment tools to 
provide feedback to students' work allows teachers to build on and support students' production of digital texts.

\section{Benefits and Promises}

The digital teaching courseware can offer the students abundant information; more plentiful than textbooks, and help them to get of displays vivid cultural background, rich content and trueto-life language materials, which are much natural and closer to life. All these avenues help students to gain an insightful understanding of foreign culture and language studied.

Multimedia enhances teaching effect and enriches teaching content and makes the best of class time and breaks the "teacher centered" teaching pattern and fundamentally improves class efficiency. The utilization of multi-media sound lab materializes the individualized and co-operative teaching, multimedia technology goes beyond time and space, creates more vivid, visual, authentic environment for English learning, stimulates students' initiatives and economizes class time meanwhile increases class information.

Digital teaching stresses the role of students, and enhances "interaction" between teachers and students. A major feature of multimedia teaching is to train and improve students' ability to listen and speak, and to develop their communicative competence, during this process,

the teacher's role as a facilitator is particularly prominent.

Digital teaching creates a context for language teaching. This method makes the class lively and interesting, as well as optimizing the organization of the class. Multimedia has its own features such as visibility and liveliness. Teachers can use pictures and images to enrich the content of classes, and also imagine different contexts in the process of producing teaching courseware. Zhang (2006:11.1) points out through Multimedia and network technology we can offer students not only rich, sources of authentic learning materials, but also an attractive and a friendly interface, vivid pictures and pleasant sounds, which to a large extent overcomes the lack of authentic language environment and arouses students' interest in learning English. In addition, digital teaching is also flexible. It is obvious that the context can be created not only in the classroom, but also after class. Multimedia language teaching can also create a language environment for the purpose of conducting language teaching

Digital teaching can foster dialogic and emancipatory practice, in which students are active, engaged and empowered participants in a conversation from which learning emerges. It also provides a platform in which an individual student's ideas go beyond the learning prescribed by the teacher/syllabus as they draw 
on knowledge gained outside formal education to construct understanding.

Digital technology can often also be exciting for learners and offers a potentially more engaging alternative. At the same time, it is important to be aware that some learners may be less confident in learning with digital technologies and steps need to be taken to ensure equality of access. Digital teaching makes learning more fun. Students prefer technology because they believe that it makes learning more interesting and fun. They especially like laptops and tablets. Subjects that students deem challenging or boring can become more interesting with virtual lessons, through a video, or when using a tablet.

Technology prepares students for the future. A study by Becta (2006) showed that 9 out of 10 students indicated that using technology in the classroom would help prepare them for the digital future. This can be done by the many opportunities for language practice it provides. Students can play with language and the context and it is more informal. They can get involved in the writing process by posting blog entries, editing to other pages, creating their own eportfolios.

Digital teaching helps students learn at their own pace. For example, almost all apps allow for individualized instruction. Students can learn according to their abilities and needs. This form of teaching is also great for the teacher because it gives $\mathrm{him} / \mathrm{her}$ the time to work individually with students who may be struggling. With electronic resources, teachers could easily give students different assignments and assessments designed specifically around each student's growth targets. It allows users to become the producers of the knowledge. Using Web 2.0 or later versions enable us to share our work with other audience. For example, E-pals project is considered to be the world's largest online classroom.

Technology connects with students. Technology occupies an important place within students' lives. These technologies offer structures and support for student-student and teacher-teacher collaboration. It engages students. It also helps us to motivate our shy students to participate more in our lessons and the willingness to create and share is a great opportunity to learn and participate. Using Web 2.0 for instance can easily create social networks and communities of interest. Wikipedia and Ning are the best examples for this and they are all free.

Technology helps in making diagnosis and intervention. When student work is done online, teachers are able to receive immediate results and students to get prompt feedback. This immediacy enhances both the grading process and student learning. Teachers quickly address 
student misconceptions, lack of content background, or need for practice.

Technology increases the creativity. Any student can write film and publish a video or an audio. YouTube and Google video are used by our students every day. They watch more videos on YouTube than they watch on T.V. or cinemas.

\section{Problems and Challenges}

In spite of advantages of application of digital teaching in English language classes, there are many problems existing in practical teaching, such as:

Teachers and schools need to think carefully about when, why and how to use technologies as well as evaluating their efficiency and effectiveness.

- There is a 'digital divide' - the divide between those who have access to digital technology and the internet, and those that do not.

$\circ$ Implementing and then maintaining technology is costly particularly as systems can quickly become out of date.

○ There may be problems with the existing infrastructure, for example internet connections may be inconsistent and/or slow.

- Safety for students and teachers is a key challenge with prevention of cyberbullying, the hacking of personal information, access to illegal or banned materials and distractions from learning (such as social networking and mobile phone use) all being high on institutional agendas.

- Some uses of technologies can be harmful. For example, poor posture and eyestrain are common problems when working at desktop computers for prolonged periods. Also Repetitive Strain Injury (RSI) is a risk that occurs from the repeated actions necessary to control mobile devices.

- Whereas, the introduction of multimedia technology featuring audio, visual, textual effect fully meets audio and visual requirements of the students and enhance their interest, but it also results in lack of oral communication between teachers and students, replacement of teachers' voice by computer sound, and teachers' analysis by visual image and students have' few chances for speaking communication.

It is clear that language teaching is different from science subjects, for language teaching does not require demonstration by various steps, rather, the tense and orderly atmosphere is formed through questions and answer between teachers and students, Teachers raise impromptu and real-time questions and guide the students to 
think, cultivate their capacity to discover and solve problems, however, due to over demonstration and pre-arranged order, the courseware lacks real-time effect and cannot give feedback, consequently, this can limit students' creative thinking potentials.

Teacher support of the use of digital technologies in the classroom

Teachers can make the best use of technology in the classroom by developing their awareness of a range of digital technologies and considering carefully both how and why they can be used to support students' learning. Effective selection of software and devices is only part of the story. The consideration of what learning will be achieved and how the technology may help is fundamental to its effective deployment.

The SAMR (Substitution, Augmentation, Modification, and Redefinition) model developed by Dr Ruben Puentedura is a useful reference when considering the implementation of technology in the classroom.

This task can at times seem daunting with a constant plethora of new sites, apps and resources constantly emerging whilst many of the trusted resources we have used in the past can quickly seem outdated or disappear altogether. It is for this reason that a number of eBooks and lesson plans have been prepared by Peachey (2015) to help teachers by providing

them with up-to-date information about new and existing resources and by simply classifying them to make it easier to find tools and resources that match their aims and purpose.

The sites, apps and resources within these books have been divided into chapters like the following: Reading Tools, Writing Tools, Speaking Tools, Listening Tools, Grammar Tools, Presentation Tools, Poll \& Survey Tools, Infographic Tools, and Course Creation Tools. All of the tools and resources selected for these books are either free or have a useable permanent freemium offering, so you will never be forced to pay for any of these resources in order to sustain the work you are doing with your students.

\section{Lesson Plans}

Each of these lesson plans constitutes between 90 and 180minutes of study and can be used in part as simple conversation classes or in total for deeper research projects. All lesson plans are included in 'Thinking Critically through Digital Media' and a selection of 10 are included in 10 Lessons in Digital Literacy' (A World without Magnets; Breakfast around the World; Perceptions of Advertising; Emotional Intelligence; Careers for Introverts \& Extroverts The Science of Happiness; The History of Weddings; Studying How to Study; 50 Facts about Hair; Body language; Mind your Waste; 
and The Habits of the World's Wealthiest People).

\section{Methods used in Digital Teaching}

Lecture capture, This technology, which automatically records a classroom lecture, was originally designed to enhance the classroom model by making lectures available for repeat viewings online at any time for students regularly attending classes - in other words, a form of homework or revision.

* Flipped classrooms, which pre-record a lecture for students to watch on their own, followed by discussion in class, are an attempt to exploit more fully this potential, but the biggest impact has been the use of lecture capture for 'instructionist' massive open online courses (xMOOCs), such as those offered by Coursera, Udacity and edX. However, even this type of MOOC is really a basic classroom design model. The main difference with a MOOC is that the classroom is open to anyone (but then in principle so are many university lectures), and MOOCs are available to unlimited numbers at a distance.

\section{* Learning management systems (LMSs) are} software that enables instructors and students to $\log$ in and work within a password protected online learning environment. Most learning management

systems, such as Blackboard, Desire2Learn and Moodle, are in fact used to replicate a classroom design model. They have weekly units or modules, the instructor selects and presents the material to all students in the class at the same time, a large class enrolment can be organized into smaller sections with their own instructors, there are opportunities for (online) discussion, students work through the materials at roughly the same pace, and assessment is by end-of-course tests or essays.

The main design differences are that the content is primarily text based rather than oral (although increasingly video and audio are now integrated into LMSs), the online discussion is mainly asynchronous rather than synchronous, and the course content is available at anytime from anywhere with an Internet connection. Nevertheless, the LMS is still an advance over online designs that merely put lectures on the Internet as prerecorded videos, or load up pdf copies of PowerPoint lecture notes, as is still the case unfortunately in many online programs.

The concurrence of both constructivist approaches to learning and the development of the Internet has led to the development of a particular form of constructivist teaching, originally called computer-mediated communication (CMC), or networked learning, but which has been developed into what 
Harasim (2012) now calls online collaborative

learning theory (OCL). She describes OCL as follows (p. 90):

OCL theory provides a model of learning in which students are encouraged and supported to work together to create knowledge: to invent, to explore ways to innovate, and, by so doing, to seek the conceptual knowledge needed to solve problems rather than recite what they think is the right answer. While OCL theory does encourage the learner to be active and engaged, this is not considered to be sufficient for learning or knowledge construction.......In the OCL theory, the teacher plays a key role not as a fellowlearner, but as the link to the knowledge community, or state of the art in that discipline. Learning is defined as conceptual change and is key to building knowledge. Learning activity needs to be informed and guided by the norms of the discipline and a discourse process that emphasizes conceptual learning and builds knowledge.

cMOOCs have the most potential, because lifelong learning will become increasingly important, and the power of bringing a mix of already well educated and knowledgeable people from around the world to work with other committed and enthusiastic learners on common problems or areas of interest could truly revolutionize not just education, but the world in general.

\section{References}

Abu Bakar, A (2016) "Digital Classroom": An Innovative Teaching and Learning Technique for Gifted Learners Using ICT, Creative Education, 7, 55-61Published OnlineinSciRes.http://www.scirp.org/journal/ cehttp://dx.doi.org/10.4236/ce.2016.71006

Peachey N (2014) Digital Tools for Teachers. Available from http://peacheypublications.com/

Alsied, Safia $M$ and Pathan, Mustafa M (2013). The Use of Computer Technology in EFL Classroom. International Journal of English Language \& Translation Studies 1, (1).

Beach, R. (2012) Uses of Digital Tools and Literacies in the English Language Arts Classroom, Research in the Schools, MidSouth Educational Research Association 19, (1) $1,45-59$

Becta (2006). Benefits and features of ICT in English. ICT in the Curriculum. Retrieved on April $11^{\text {th }} 2006$ from http://curriculum.becta.org.uk/docserver.php/ ?docid $=657$

Becta (2006). ICT in the Curriculum. Retrieved on April 11 2016 from http://curriculum.becta.org.uk/docserver.php? temid $=255$.

Beetham, H. and Sharpe, R. eds (2007) Rethinking Pedagogy for a Digital Age: Designing and Delivering E-Learning. London: Routledge. Cambridge professional 
development qualifications for Teaching with Digital Technologies: www.cambridgeinternational.org/pdq.

Celik, S and Aytin, K (2014) Teachers' Views on Digital Educational Tools in English Language Learning: Benefits and Challenges in the Turkish Context. TESL-EJ $18,(2)$.

European Parliament (2015) Innovative Schools: Teaching and learning in the Digital Era. EP Directorate General for internal Policies.

Fredriksen, E (2017) The Digital Space in the English Classroom: A study of the use of digital tools in the teaching of EFL in the Norwegian Upper Secondary School, MA thesis, University of Bergen, Norway.

Haelermans, C (2017) Digital Tools in Education. On Usage, Effects and the Role of the Teacher. SNS Förlag.

Jenkins, R (2015) Integrating Digital Literacy into Language Instruction. Companion Learning Resource A project of American Institutes for Research Available at: https://lincs.ed.gov/programs/eslpro

Luckin, R., Bligh, B., Manches, A., Ainsworth, S., Crook, C. and Noss, R. (2012) Decoding Learning: The Proof, Promise and Potential of Digital Education. London: Nesta.www.nesta.org.uk/library/documents/ DecodingLearningReport_v12.pdf. Dr Ruben Puentedura's Weblog: www.hippasus.com/rrpweblog.
Moon, Bob and Villett, Charmaine (2016). Digital Learning: Reforming Teacher Education to Promote Access, Equity and Quality in Sub-Saharan Africa. Commonwealth of Learning, Vancouver.

Padmavathi, G (2013) English teaching and learning in the Digital Age International Journal of Modern Engineering Research (IJMER) 3, (1).

Richard Beach (2012) Uses of Digital Tools and Literacies in the English Language Arts Classroom RESEARCH IN THE SCHOOLS Mid-South Educational Research Association 2012, Vol. 19, No. 1, 45-59.

Shyamlee1, Dand Phil, M (2012) Use of Technology in English Language Teaching and Learning": An Analysis. International Conference on Language, Medias and Culture IPEDR vol.33.

Wegerif, R. (2012) Dialogic: Education for the Internet Age. London: Routledge. Useful websites: Edudemic: www.edudemic.com, Association for Learning Technology: www.alt.ac.uk Future lab at NFER: www.futurelab.org.uk Cambridge Assessment Digital Education (2017) Digital technologies in the classroom. Retrieved from www.cambridgeinternational.org. 